\title{
Fern Habitats and Rare Ferns in Oklahoma
}

\author{
Dr. Bruce A. Smith \\ McLoud High School \\ McLoud, Oklahoma \\ E-mail: fronds02@yahoo.com
}

This paper features some of the more common fern habitats in Oklahoma and provides information on four rare Oklahoma ferns from two fern families: Aspleniaceae and Pteridaceae. Surprisingly, ferns can be found in a variety of habitats across Oklahoma.

\section{INTRODUCTION}

With over 2500 species of vascular plants (Taylor and Taylor 1991), Oklahoma is rich in both plant and habitat diversity. The vast majority of Oklahoma's vascular plants are flowering plants. Less than 100 species are ferns and fern allies. Needless to say, ferns and fern allies do not get the same attention as do flowering plants. One obvious reason is that they are not as showy and do not catch our eye as wildflowers do. Secondly, we tend to visit wildflower habitats more often than fern habitats. Ferns live in some of the most interesting places, however. If you are in the Quartz Mountains you may be staring at a western diamondback snake and a star cloakfern on the same rock. If you are hunting the netted chain fern in southeastern Oklahoma you may be up to your ankles in mud. One of the objectives of this article will be to introduce you to some of the typical habitats and places that you can find ferns. You will also be introduced to some of the rare ferns of Oklahoma.

Habitat information for some of the species is from The Flora of North America (1993). Rare species are those listed in the Oklahoma Natural Heritage Inventory (2005). Collection dates and distribution information are from the Oklahoma Biological Survey Database and from personal encounters with the species. Authority and common names are from Taylor and Taylor (1991) and The Flora of North America (1993). Technical descriptions of each species can also be obtained from The Flora of North America. To distinguish between the different taxa I would encourage readers to use field guides and a good dichotomous key such as Keys and Descriptions for the Vascular Plants of Oklahoma (Tyrl et al. 2007) or the Illustrated Flora of North Central Texas (Diggs et al. 1999).

\section{FERN HABITATS}

One of the best places to look for ferns is on rock outcrops with mosses. Rocks are great places to find ferns, no matter what part of the state you are in. Ferns can even be found embedded in mosses on trees. If you can't find them on rocks and trees, look for them in marshes, bogs, mudflats, woodland forests, areas with rocky soils, near waterfalls, and even floating on the water surface. The places you will likely not find them are in lawns or prairies. Often, when someone has brought or described to me the leaf of a "fern" they found in such a habitat, it has been Achillea millefolium L., the common yarrow. Common yarrow is a flowering plant in the composite family Asteraceae.

Do not let the rocky outcrop habitats in Quartz Mountain Resort, or other islands of the Wichita Mountains (Fig. 1), discourage you from looking for ferns. Southwestern Oklahoma is a great place to see several families of ferns including the Aspleniaceae, Dryopteridaceae, and especially the maidenhair family, Pteridaceae.

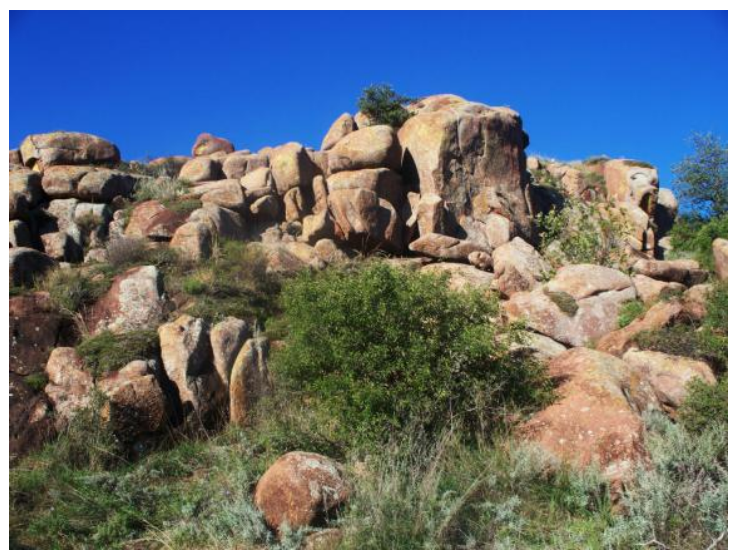

Figure 1 Rock outcrop, Quartz Mountain Resort. 
The overhang of the cave at Robbers Cave State Park and Lodge supports a healthy population of Asplenium bradleyi D.C. Eaton, Bradley's spleenwort, one of Oklahoma's rarer ferns (Fig. 2). I have visited this same population many times over the years. The population appears to have grown and is healthier than ever.

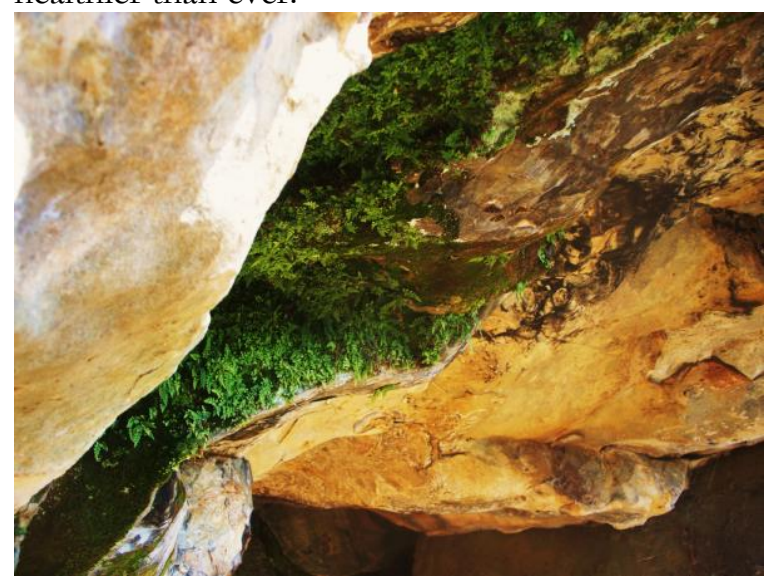

Figure 2 Rock outcrop overhang of Robbers Cave.

Limestone crevices can hold lichens as well as Argyrochosma dealbata (Pursh) Windham, the powdery cloak-fern (Fig. 3). The Arbuckle Mountains are great places to see several species of ferns, especially the maidenhair ferns.

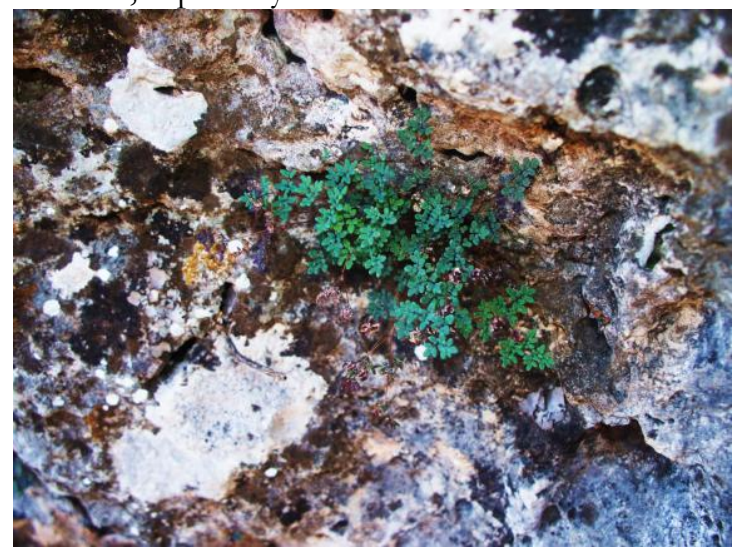

Figure 3 Argyrochosma dealbata in limestone crevice with lichens, Turner Falls in the Arbuckle Mountains.

Cheilanthes lanosa (Michx.) D.C. Eaton, the hairy lipfern, grows on rocky soil with a spike moss on Elk Mountain in the Wichita Mountains (Fig. 4). Other granitic rocks on which to find this fern are in the Great Plains State Park and Quartz Mountain Resort.

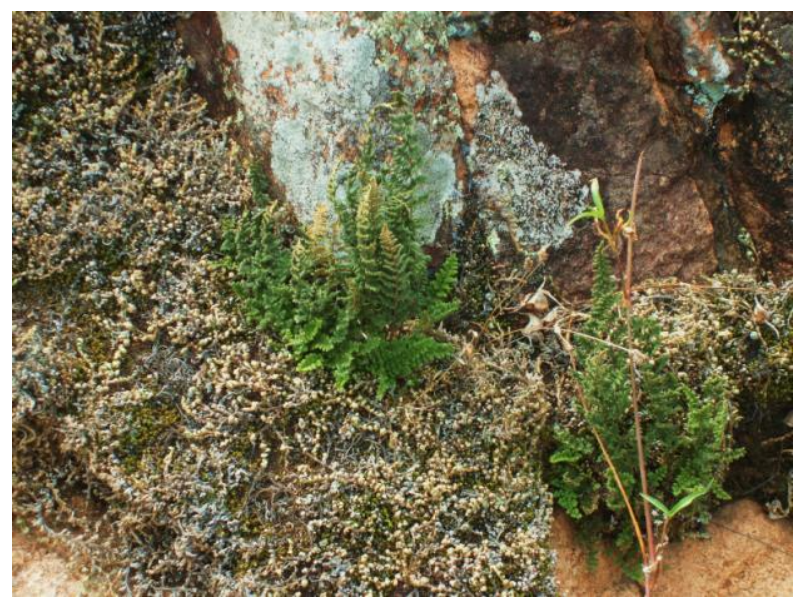

Figure 4 Cheilanthes lanosa with spike moss.

Cheilanthes lanosa also grows on other rock types such as the limestone at Beavers Bend Resort Park and Robbers Cave State Park and Lodge. This fern is one of the few in Oklahoma that has the ability to take over large patches of hillsides in open areas (Fig. 5).

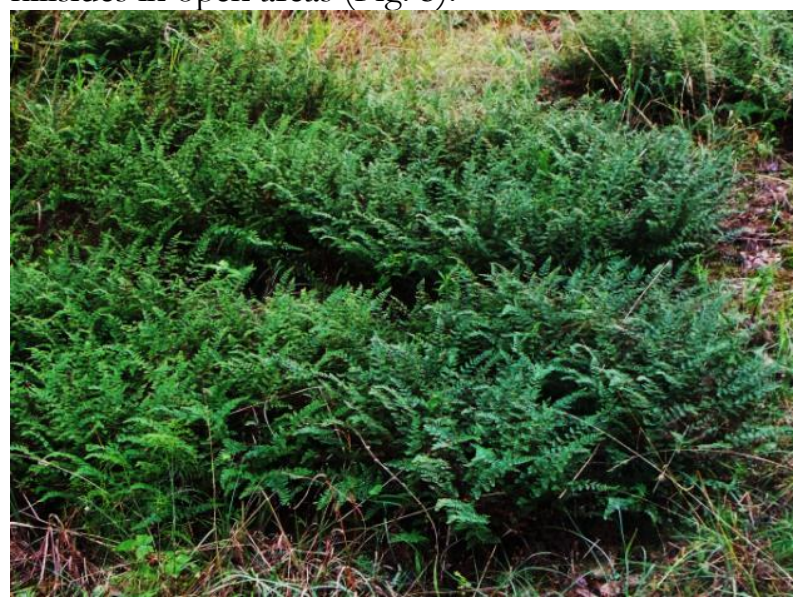

Figure 5 Cheilanthes lanosa in an open area, Beavers Bend Resort Park.

I do not know of any Oklahoma epiphytic ferns other than Pleopeltis polypodioides (L.) Andrews \& Windham (figs. 6 \& 7), the resurrection fern. It is common in eastern forests on both mossy covered rocks and mossy covered trees. It occurs as far west as Johnston County. 


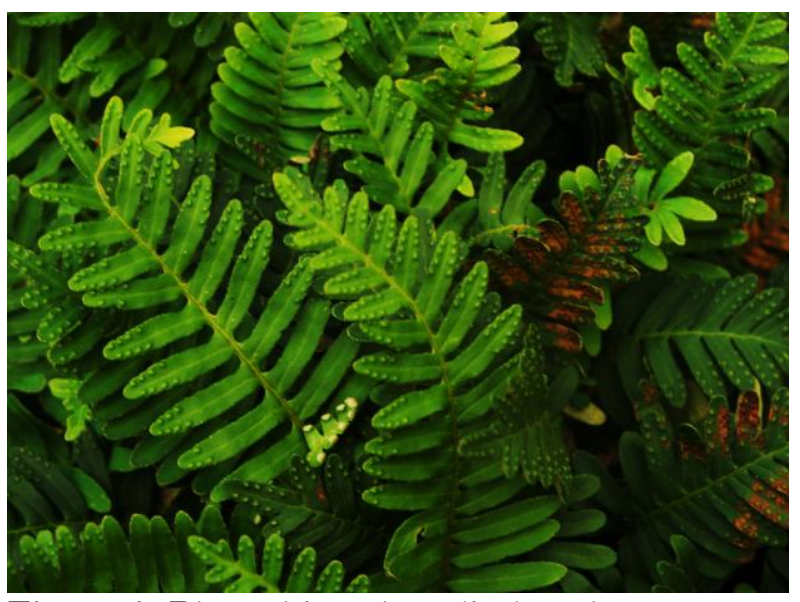

Figure 6 Pleopeltis polypodiodes, the resurrection fern, in Idabel City Park.

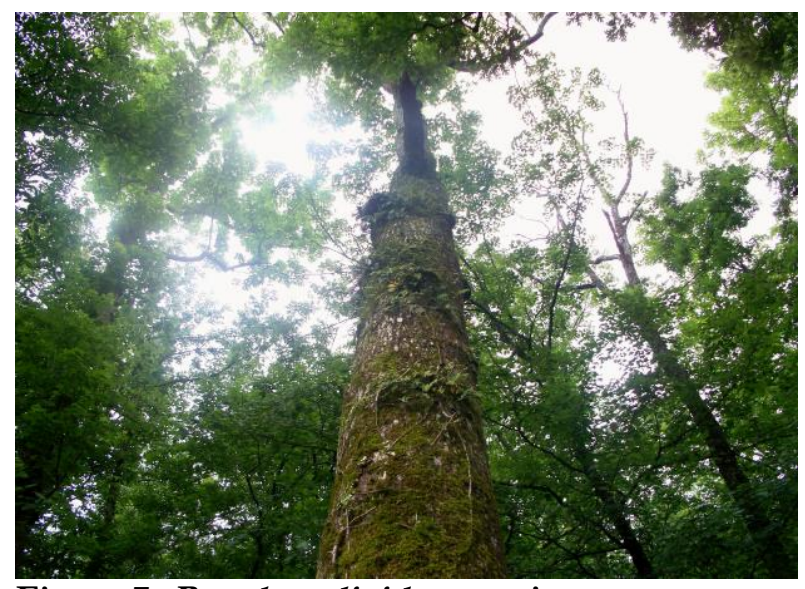

Figure $7 \quad P$. polypodioides growing as an epiphyte.

Osmunda cinnamomea L., cinnamon fern, grows under the canopy of a mesic forest in Choctaw County (Fig. 8). Cinnamon ferns can live in acidic soils, vernal seeps, and moist areas. Cinnamon ferns can be seen on public land at Ferndale Bog in McGee Creek State Park. The best time to visit them is in May when you can see their cinnamon colored fertile fronds.

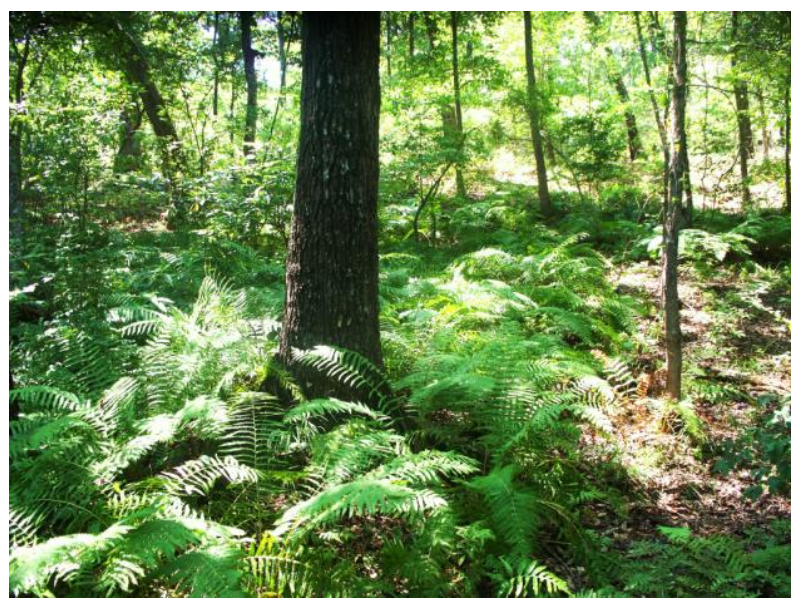

Figure 8 Cinnamon fern in Choctaw County

Woodwardia areolata (L.) T. Moore (Fig. 9) grows in wet forest soils in Choctaw County, but they can also be found in seeps and acidic bogs. Look carefully at the erect fertile frond in the foreground. The elongated sori of each leaflet fit end to end forming a chain, thus the common name, netted chain fern. Growing laterally in the background you can see the sterile fronds that do not produce sori. Both fronds are part of the same rhizome. This is an interesting species to see, especially when both types of fronds are present. It is a southeastern Oklahoma species that can be seen in at least five counties.

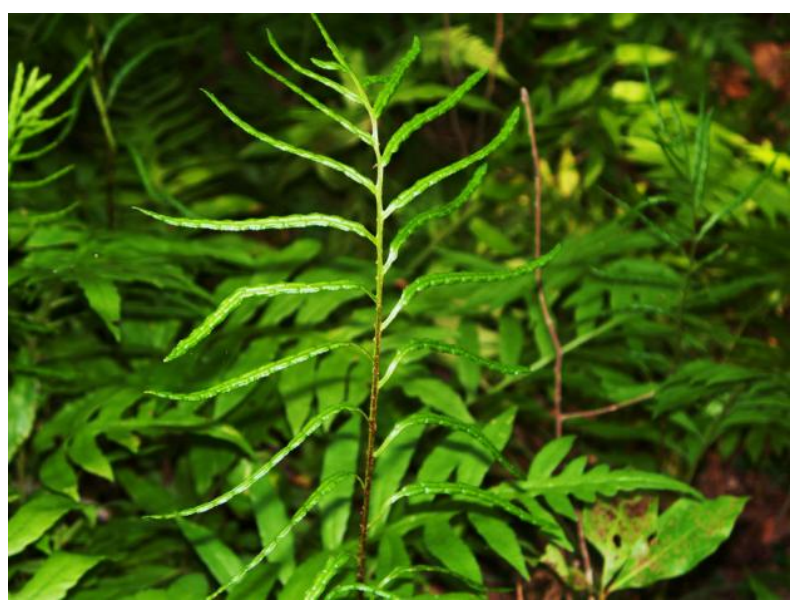

Figure 9 Woodwardia areolata with fertile frond in foreground.

Onoclea sensibilis L. (Fig. 10) grows in marshy soils on McCurtain County roadsides. Sensitive ferns can be found in open swamps, thickets, 
marshes, or lowland woods. Like Woodwardia areolata, the sensitive fern has separate fertile (brown) fronds and sterile (green) fronds. This species has a much wider distribution than the netted chain fern. The sensitive fern is seen as far west as Creek County.

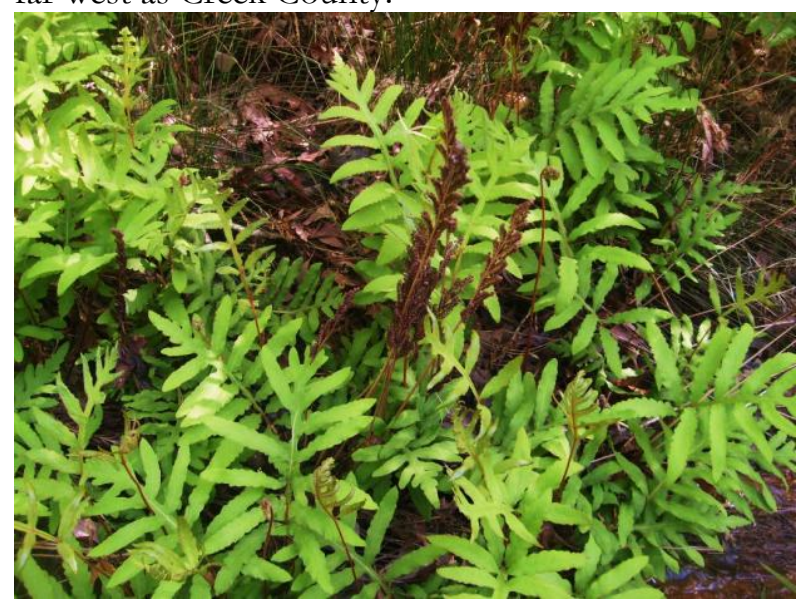

Figure 10 Onoclea sensibilis with fertile brown fronds.

Mudflats like the one at the University of Oklahoma Biological Station in Marshall County are not the greatest habitat to look for ferns (Fig. 11). However, Marsilea vestita Hook. and Grev., water clover, was collected there in 2006.

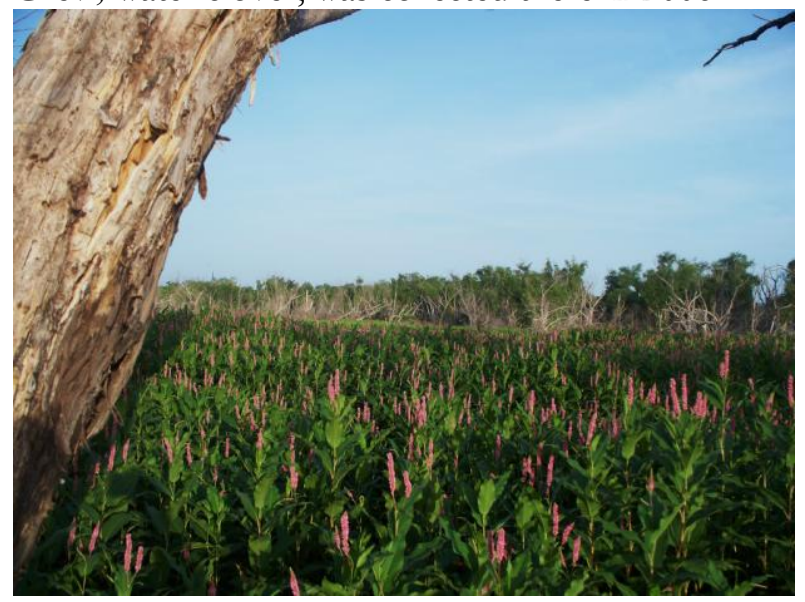

Figure 11 Mudflat habitat at OU Biological Station.

On the falls and rocks in the creek area at Price Falls in Falls Creek Baptist Assembly (Fig. 12) you can see Adiantum capillus-veneris L., the southern maidenhair fern. The tissue thin fronds require moist cool air to survive. Climb fifteen feet above the waterfall on the rock and away from the creek and you will not find it. Falls Creek is a wonderful place to find several species of the Pteridaceae: Adiantum capillus-veneris, Argyochosma dealbata, Astrolepis integerrima (Hook.) Benham \& Windham, Cheilanthes tomentosa L., and Pellaea atropurpurea (L.) Link.

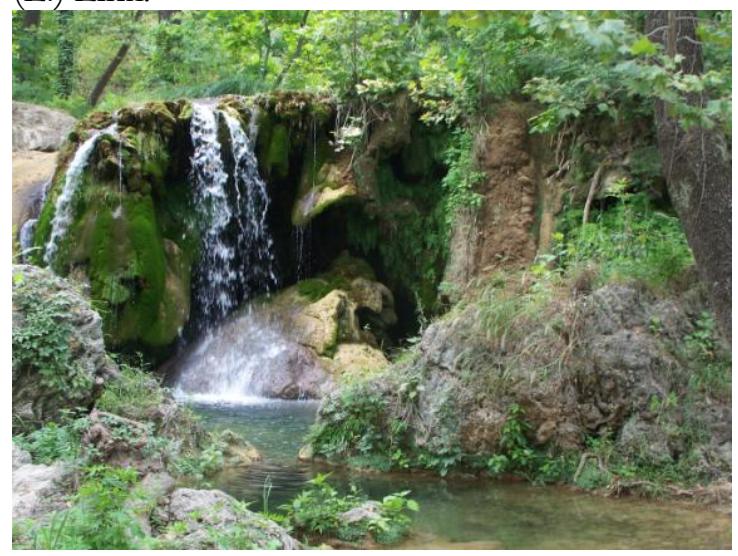

Figure 12 Price Falls at Falls Creek Baptist Assembly.

\section{RARE FERNS}

I do not remember when I first became a "Pteridomaniac". The spore must have begun developing in 1977 after enrolling in my first field botany course, Plant Taxonomy, under Dr. Doyle McCoy. Since 1977 I have taken my share of botany field trips all over the state. In fact, I consider every day a botany field trip, always looking for that fern or other plant that I have never seen as well as those "old friends", as Dr Tyrl would call them, like Asplenium platyneuron (L.) Britton, Sterns \& Poggenb. (Fig. 13) and Woodsia obtusa (Spreng.) Torr. (Fig. 14), two ferns that are as common as dandilions.

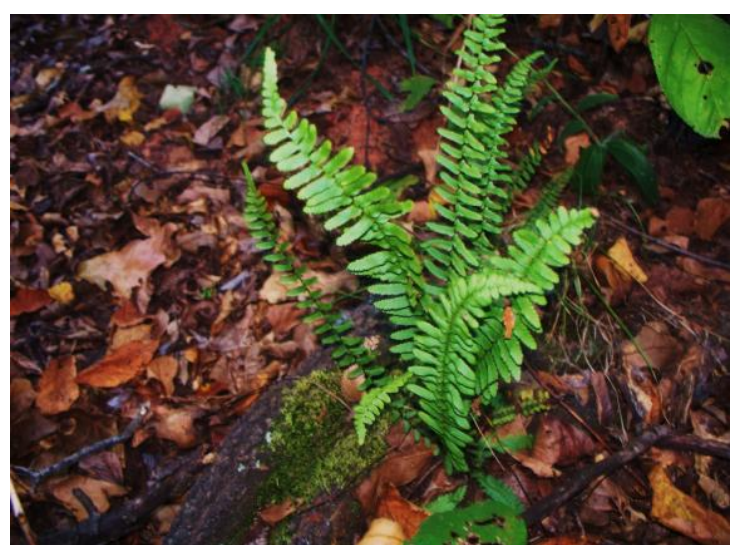

Figure 13 Asplenium platyneuron, ebony spleenwort, a very common fern. 


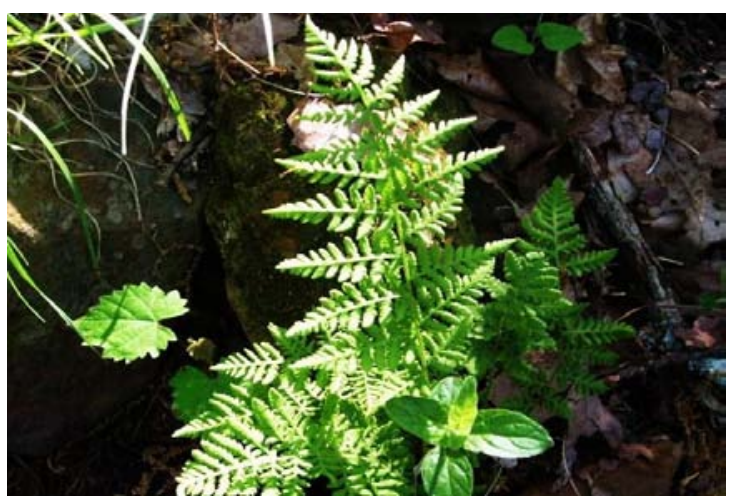

Figure 14 Woodsia obtusa, blunt-lobed cliff fern, another common fern

The following species are relatively rare in Oklahoma and are listed as "species of concern" by the Oklahoma Natural Heritage Inventory (2008). The first three are in Aspleniaceae family and the last is in Pteridaceae. I have had the good fortune to see each of them more than once, some in multiple locations, others in only one location.

\section{Asplenium bradleyi D.C. Eaton (Fig. 15)}

Common name: Bradley's spleenwort

Distribution: Latimer County, also seen in

Atoka County.

Note: This is a difficult species to describe, but it can easily be identified using a field guide or dichotomous key.

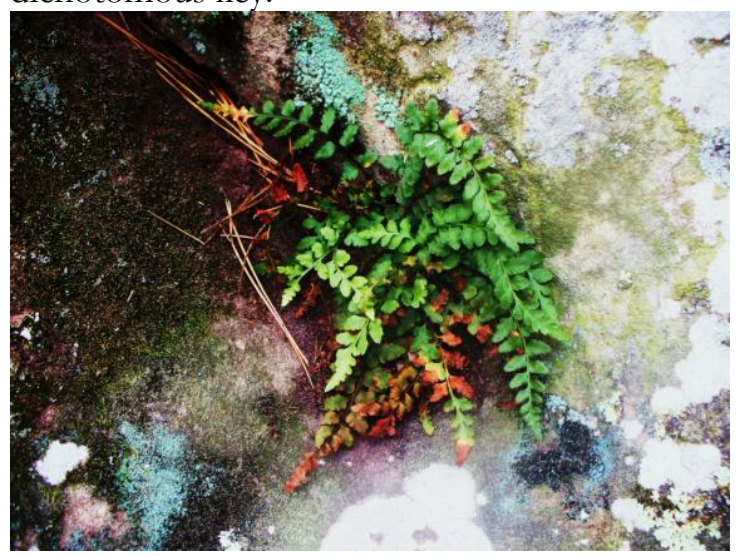

Figure 15 Asplenium bradleyi growing on sandstone rock, Robbers Cave State Park and Lodge.
Asplenium pinnatifidum Nutt. (Fig. 16)

Common name: lobed spleenwort

Distribution: Latimer County.

Note: this species has only been reported at Robbers Cave State Park and Lodge, but there are several populations throughout the park, including Robbers Cave.

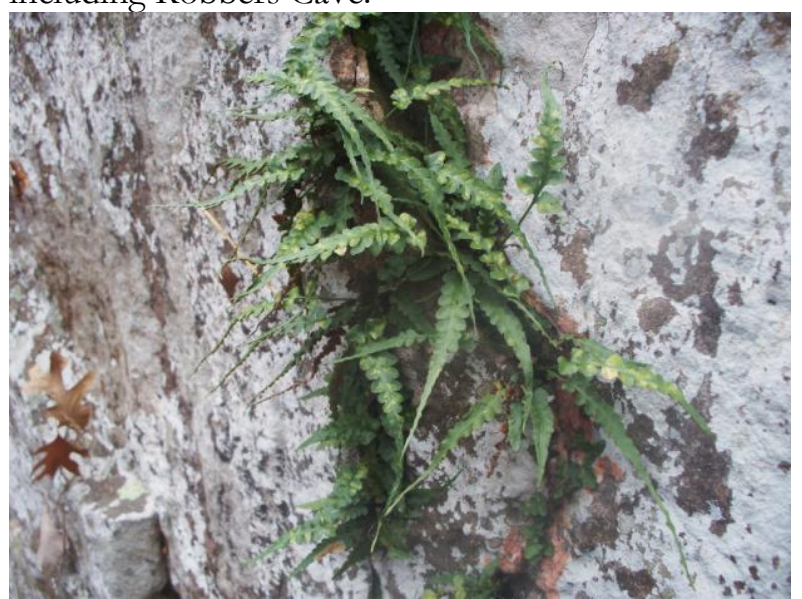

Figure 16 Asplenium pinnatifidum, Robbers Cave State Park and Lodge.

Asplenium septentrionale (L.) Hoffm. (Fig. 17) Common name: forked spleenwort Distribution: Cimarron County.

Note: This fern does not have the typical fern appearance. The novice might even mistake it for a grass. The fronds have a grass-like appearance with narrow linear blades. The blade apex can be forked, thus its common name.

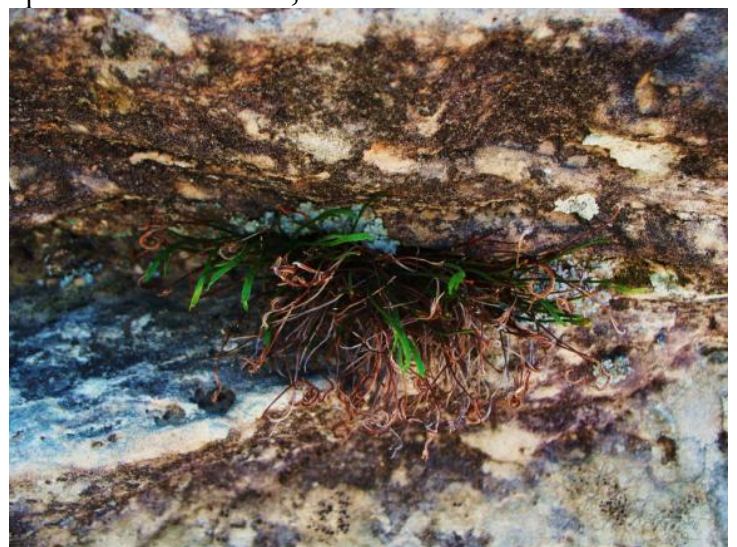

Figure 17 Asplenium septentrionale, north of Black Mesa State Park and Nature Preserve. 
Cheilanthes wootonii Maxon (Fig. 18)

Common name: beaded lipfern

Distribution: Cimarron, Greer, and Kiowa counties, but also seen in Canadian County. Note: Cheilanthes species are difficult to identify. C. wootonii Hook. can easily be mistaken for $C$. eatonii Baker, C. tomentosa Link, or even $C$. lindheimeri. You'll need a good dichotomous key such as Keys and Descriptions for the V ascular Plants of Oklahoma (Tyrl et al. 2007) to identify members of this genus.

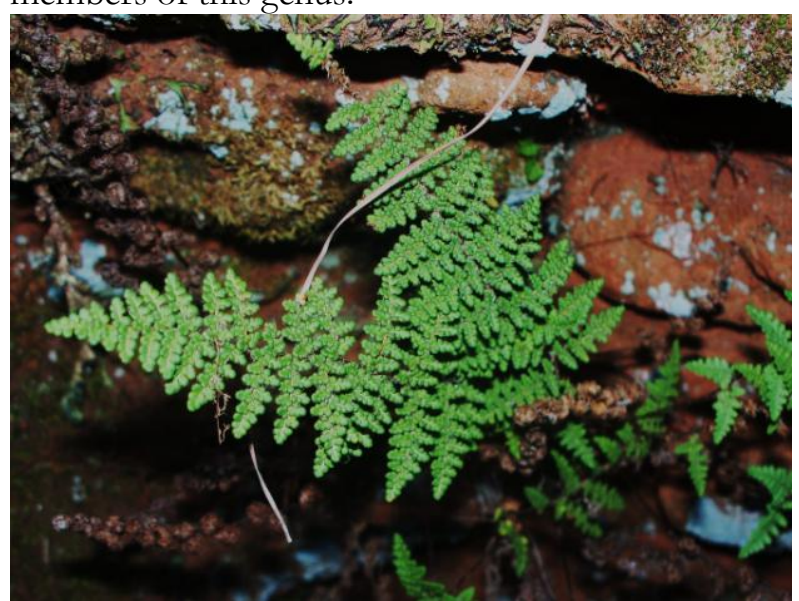

Figure 18 Cheilanthes wootonii, Methodist Canyon Camp.

\section{CONCLUSION}

I hope you will visit a fern habitat on a future field trip. You do not need to wait until spring to see ferns because there are several species in our state that are evergreens. You will find ferns to be both fascinating and beautiful. If you are fortunate enough to come across one of these rare ferns, please practice good conservation by not collecting it and by protecting its habitat.

\section{ACKNOWLEDGEMENTS}

My thanks to the following individuals: Richard Butler for accompanying me on many field trips the last five years and helping to edit portions of the article: Mickey Cooper for giving me my start in Botany; Doyle McCoy for giving me my start in Oklahoma native plants; Ron Tyrl for training me as a botanist and providing so many great botanical opportunities; Richard Butler, Catherine Eimen, Bruce Hoagland, and Sheila Strawn, for helping to edit portions of this article; and to my wife, Sharon, for helping to edit the article and for allowing me to pursue my passion.

I also give my thanks for access to these properties: Hoby family property; University of Oklahoma Biological Station; Falls Creek Baptist Assembly; Methodist Canyon Camp; Southwest Baptist Assembly; Turner Falls; Idabel City Park; and the following state facilities: Beavers Bend Resort Park, Black Mesa State Park and Nature Preserve, Great Plains State Park, McGee Creek State Park, Quartz Mountain Resort, Red Rock Canyon State Park, and Robbers Cave State Park and Lodge.

\section{LITERATURE CITED}

Diggs GM Jr., Lipscomb BL, and O'Kennon R. 1999. Shinner's \& Mahler's illustrated flora of North Central Texas. Botanical Research Institute of Texas, Sida, Botanical Miscellany No. 6.

Flora of North America, Editorial Committee. Flora of North America. 1993. Vol 2. Pteridophytes and Gymnosperms, New York, Oxford University Press.

Oklahoma Natural Heritage Inventory. 2008. Oklahoma Natural Heritage Inventory working list of rare Oklahoma Plants. Oklahoma Biological Survey. $<$ www.oknaturalheritage.ou.edu/plants> accessed December 2008.

Taylor RJ and Taylor CES. 1991. An annotated list of the ferns, fern allies, Gymnosperms and flowering plants of Oklahoma. Biological Department Herbarium, Durant, Southeastern Oklahoma State University.

Tyrl RJ, Barber SC, Buck P, Elisens WJ, Folley PA, Magrath LK, Murray CL, Smith BA, Taylor CES, and Thompson RA. 2007. Keys and descriptions for the vascular plants of Oklahoma. Noble, Flora of Oklahoma, Inc. 